This item was submitted to Loughborough's Research Repository by the author.

Items in Figshare are protected by copyright, with all rights reserved, unless otherwise indicated.

\title{
Capturing the student user experience (UX) in York and Loughborough University Library buildings
}

PLEASE CITE THE PUBLISHED VERSION

http://dx.doi.org/10.1108/PMM-04-2016-0021

\section{PUBLISHER}

(C) Emerald Group Publishing Limited

\section{VERSION}

AM (Accepted Manuscript)

\section{PUBLISHER STATEMENT}

This work is made available according to the conditions of the Creative Commons Attribution-NonCommercialNoDerivatives 4.0 International (CC BY-NC-ND 4.0) licence. Full details of this licence are available at: https://creativecommons.org/licenses/by-nc-nd/4.0/

\section{LICENCE}

CC BY-NC-ND 4.0

\section{REPOSITORY RECORD}

Burn, Katie, Matthew S. Cunningham, Liz Waller, Emma Walton, and Graham Walton. 2019. "Capturing the Student User Experience (UX) in York and Loughborough University Library Buildings". figshare. https://hdl.handle.net/2134/22885. 


\section{eEmerald $\begin{aligned} & \text { Performance } \\ & \text { Measurement and Metrics }\end{aligned}$}

\section{Capturing the student User Experience (UX) in York and Loughborough University library buildings}

\begin{tabular}{|r|l|}
\hline Journal: & Performance Measurement and Metrics \\
\hline Manuscript ID & PMM-04-2016-0021 \\
\hline Manuscript Type: & Case Study \\
\hline Keywords: & $\begin{array}{l}\text { Learning Spaces, User Experience, Academic Libraries, Evidence Based, } \\
\text { Customer, User Behaviour }\end{array}$ \\
\hline
\end{tabular}

SCHOLARONE ${ }^{\text {I" }}$

Manuscripts 


\section{Capturing the student User Experience (UX) in York and Loughborough University library buildings}

\section{Abstract \\ Purpose}

In higher education libraries, the concept of the User Experience (UX) has increased in profile and importance. The concept of the 'student as customer' has generated much debate but there is general agreement that universities need to be more successful in meeting student expectations.

A key strategic area for university libraries has been to adapt and improve their physical spaces to ensure that they are still relevant for today's students. York and Loughborough University Libraries have both undergone building refurbishments and both are committed to monitoring and reviewing services and spaces. This work forms part of those reviews.

\section{Methodology}

There were various constraints which very much influenced the methodology. These included:

- $\quad$ avoiding survey overload

- no resource allocation

- $\quad$ an acknowledgment that the methodology employed needed to combine rigour and validity with a pragmatic approach to data collection

A joint project team was established of representatives from each university. A questionnaire created on Google Forms was administered by staff with individuals in the library and entering the data onto an iPad.

\section{Findings}

Findings provide evidence of use across a range of users along with valuable information on who is using our library spaces and for what purpose.

\section{Originality}

This research is a significant contribution to the evidence base around student's learning in universities. It benefits from the expertise and knowledge of two university libraries. As university's continue to develop learning spaces, this work will enable further investigation around what makes a successful learning space and what makes the library a destination of choice.

\section{Key Words \\ Learning Spaces, User Experience, Academic Libraries, Evidence Based, Customers, User Behaviour}




\section{Introduction}

This paper outlines the results of a joint project between Loughborough University Library and University of York Library to look at how and why students use their University Library buildings.

In 2013, the two Libraries at Loughborough and York engaged in a small scale joint project (Walton and Waller, 2014) exploring how students used technologies in their Library buildings. There was a shared awareness that students were using smart phones and laptops in the university libraries whilst at the same time accessing fixed Library PCs. The investigation allowed for a better understanding of BYOD (Bring Your Own Device) in the two institutions and it was agreed to take forward another joint investigation at a broader level.

In recent years, Loughborough and York have both invested significantly in refurbishing their physical space. In 2013 , Loughborough completed a $£ 4.8$ million project that increased library study spaces, updated different learning environments, enhanced access to Information and Communication Technologies and increased the number of fixed PCs for users. This has proved very successful and been favourably received by University staff and students. In 2012 York completed a £20m programme to develop a world-class library at the heart of the campus. The project incorporated a major refurbishment of the original The JB Morrell Library building alongside a complete reworking of the adjacent former Computer Science building effectively doubling the space of the main University Library. The development delivered a wide range of IT enabled study spaces for groups and individuals and has proved to be a great success with high occupation of the building and positive feedback on the space.

Both refurbishments had proved successful and attracted a lot of visitors but both Libraries wished to understand more about how and why the buildings were being used, and what differentiated the library as a destination for study from other learning spaces around campus. In a recent survey of 2000 students across the UK, commissioned by the Association of University Director of Estates (AUDE), 64\% of those surveyed placed the University Library as the most used facility on campus. With both University Libraries attracting high use and with this statistic in mind there was acknowledgement that this gap in understanding had to be addressed if services and facilities were to be successfully developed and delivered to improve the user experience. After further discussion, agreement was reached on the information required:

- Which university do you belong to?

- Which course do you belong to?

- What is your status

- What is the purpose of your visit today

- How often do you visit the Library

- Do you use other spaces on campus to study/work?

- Have you brought a laptop or tablet to use today?

- Can we talk to you again to talk about study space? 
For full questionnaire see Appendix 1.

These areas for investigation speak to the discussion around the future role of the physical library. University libraries are increasingly delivering digital services and moving away from print whilst technologies are becoming more and more embedded in all areas of people's lives, including their academic career. In the digital age, when it is possible to access content wherever connectivity exists, questions are raised about university library space, the importance (or not) of print to the study experience.and the challenges facing university libraries in adapting and changing their physical spaces to ensure their continued relevance.

The experience at both Loughborough and York is that the numbers of people using their Library building is increasing, despite the digital information provided. In this context we need to understand how and why the buildings are being used if they are to meet users' needs.

There was agreement between the two University Libraries that much could be gained by completing a joint, collaborative study around how the buildings were being used. It would provide an opportunity to benchmark and identify similarities and differences between the two sets of user groups. If the results from users at each institution were similar then wider conclusions might be reached about particular behaviours and needs. Collaboration also allowed the sharing of techniques and tools between institutions.

\section{Methodology}

The data collection methodology was designed to take into account various concerns:

- lengthy surveys off-putting to users

- reducing the number of surveys sent out to users

- clashes between surveys

- the need to automate data collection and analysis (no additional staffing was available for the project)

York University Library had addressed these factors previously by developing a 'grab and go' online questionnaire made up of closed questions. The questionnaire was developed using Google forms and loaded onto iPads. It was administered by Library staff approaching users as they entered or left the Library with their answers entered directly onto the iPad. Questions could be answered "Yes/No". This approach removed the need for any complex qualitative data analysis with some analysis of results being generated automatically in Google.

It was therefore decided to adapt this 'Grab and Go' approach for the study, with York compiling the online questionnaire on behalf of the two Universities. Electronic communication was used primarily throughout the study between Loughborough and York. This included e-mail, sharing material and adapting material on Google Docs, teleconferencing and videoconferencing. One face to face meeting was held to review the results and discuss the findings. The original intention had been to collect the data at exactly the same times but this did not prove possible as the two Universities had slightly different term time dates. Despite this, the questionnaires 
were completed in January / February 2015, with Loughborough doing the work approximately two weeks later than York. This meant that the questionnaire was administered at each site at the same week in the academic calendar.

Staff volunteers were used in each Library to undertake the interviews and the inputting of answers.

\section{Terminology}

Loughborough does not operate a faculty structure but York does, so to assist comparison Loughborough departments were aggregated to match the York faculties. Whilst there is some similarity in subject disciplines across both Universities in the social sciences and humanities, York has a balance between pure sciences, humanities and social sciences and has a Medical School. Whereas Loughborough combines social sciences and humanities with Engineering, Science and Sport.

\section{Survey Demographics}

733 questionnaires completed by Library users across both institutions, 495 at Loughborough, 238 at York. The data was gathered over a period of one week, and response rate differences can be attributed to Loughborough University Library doing the data collection after York and a level of competition entering!

The survey produced a considerable amount of data and a number of potential permutations. For the purposes of this paper a decision was made to narrow down the analysis by focussing on undergraduate, taught postgraduate and research postgraduate respondents and within the areas of 'purpose of visit', 'use of space outside of the library', 'academic department/faculty' and 'type of device brought'. The number of respondents that fit the demographic criteria chosen can be seen in figures 1 and 2 below

\section{Breakdown by user group}

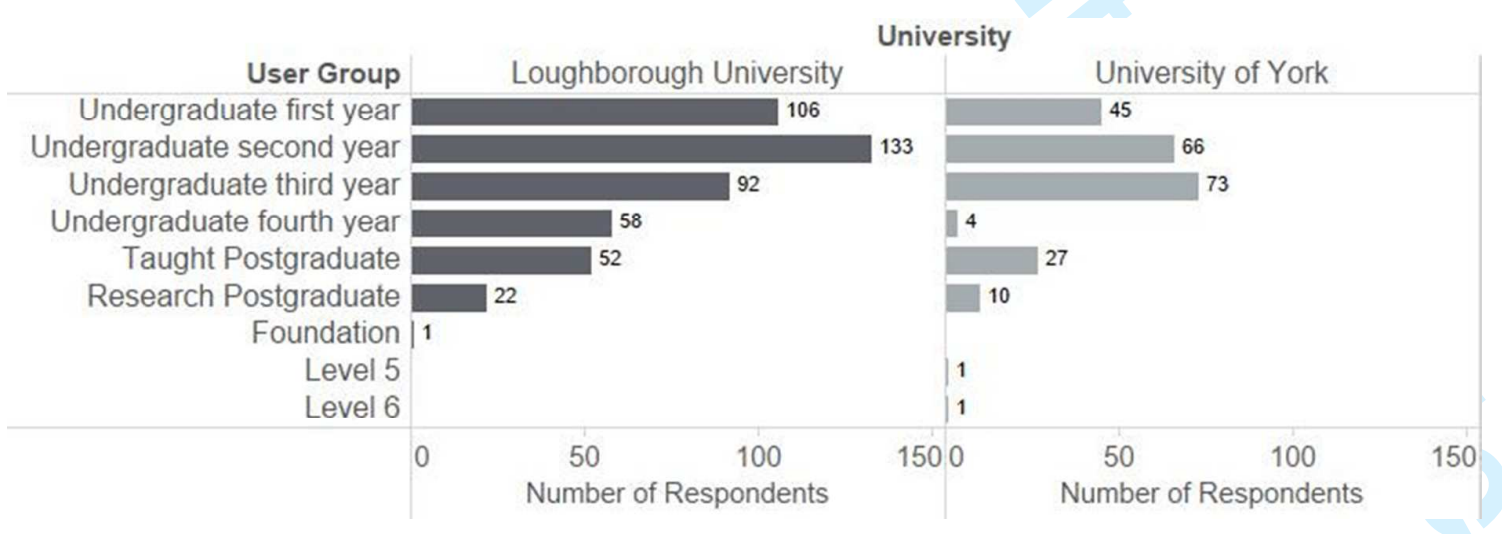

Figure.1 


\section{Breakdown by Faculty}

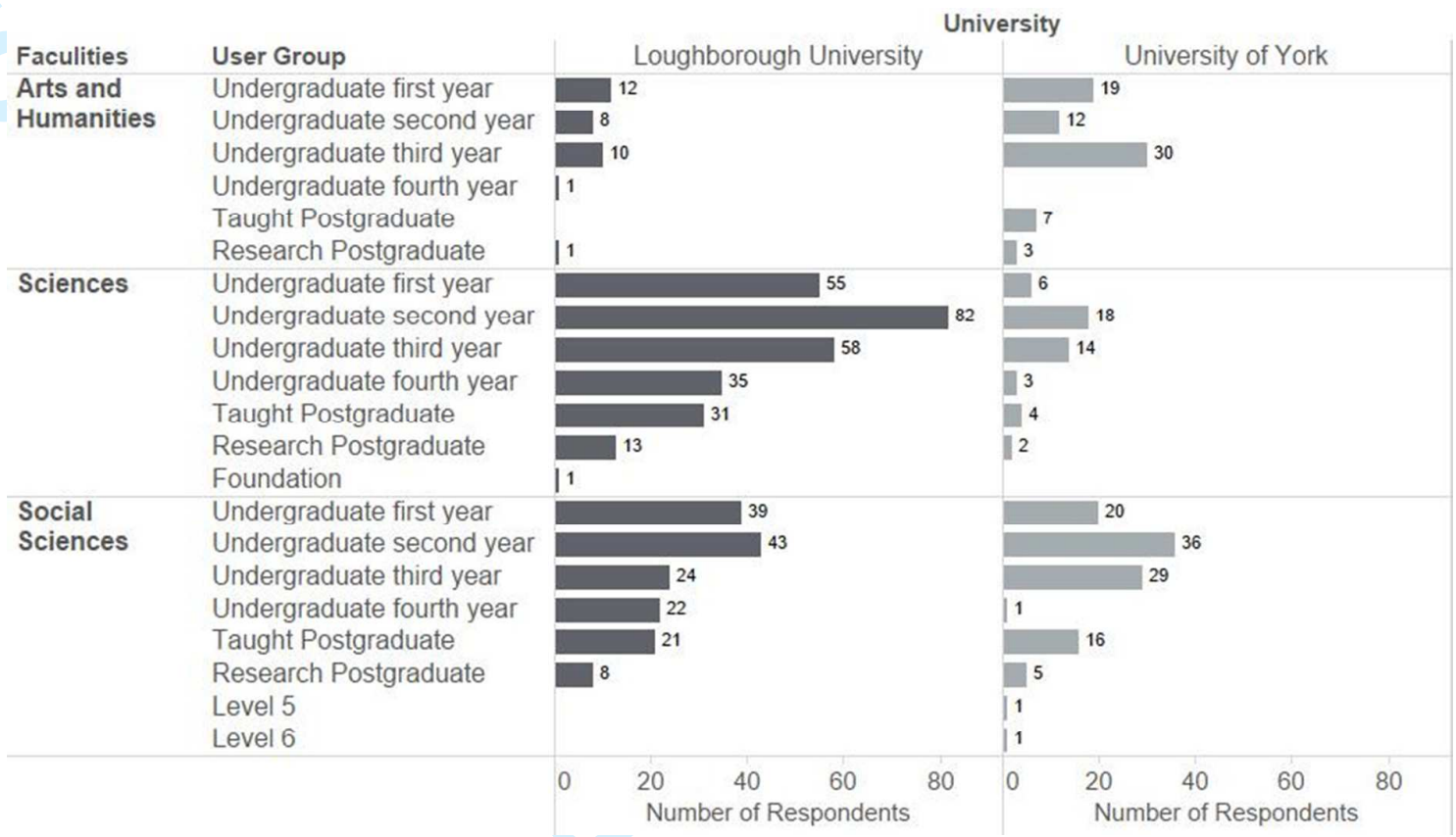

Figure.2

\section{Results}

As noted in the methodology there was a disparity between the number of respondents between Loughborough and York; $67.5 \%$ (495) were from Loughborough with $32.5 \%$ (238) from York. To allow for better comparison, each institution's data was analysed independently using Tableau software before comparisons were made.

\section{Purpose of visit for Undergraduate and Postgraduate users}

Overall the undergraduate results for Loughborough and York are very similar - the main difference being that a higher proportion of York students $(30.19 \%)$ are using the Library for individual study (18.71\% at Loughborough). Printing and photocopying feature in the results for UGs at Loughborough $(11.72 \%)$ but not highly at York $(5.3 \%)$ and meeting friends whilst listed at York $(8.75 \%)$ is not strongly featured at Loughborough (3.86\%). Generally students used a wider range of services at Loughborough than at York.

For PGs again use for individual study is much higher at York $(30.19 \%)$ than at Loughborough (18.71\%).

\section{Purpose of visit by Faculty}


For this section it was decided that we would look at results at an overall faculty level, taking into account both the undergraduate and postgraduate data.

At York "Finding an individual study space" is the most popular reason for visiting the Library. The common reasons for visiting the Library across the three Faculties are:

- Finding an individual study space

- Borrow or return items

- Finding a group study space

Arts \& Humanities (19.01\%) and Social Sciences ( $17.88 \%$ ) both rank "Using Library resources to study" whilst for the Science students that responded to the survey this is not a significant purpose (3.39\%).

The Library as a "social" venue also shows strongly at York with Art \& Humanities listing "To meet friends/socialise" in their top five, Social Sciences listing "To use the Library cafe" and the Sciences listing both of these in their top five.

At Loughborough the results show that the use of the library is split more equally between the facilities and the use of space itself. Both Arts and Humanities (30\%) and the Social Sciences $(21.57 \%)$ use the library primarily for borrowing and returning items whilst the Sciences top use was for group study space (16.8\%). However using the library for individual study space (16.6\%) and borrowing and returning items (14.98\%) were quite close in ranking for the sciences also.

Visiting the library to use a PC or to photocopy and print showed more significant use at Loughborough across the Sciences (13.36\% and $9.72 \%$ respectively) and Social Sciences $(9.80 \%$ and $14.12 \%)$ than at York where these figures were consistently below $6 \%$.

\section{Comparing results across Loughborough and York}

Arts \& Humanities are similar in four of the top five purposes for visits:

- Finding individual study space (York 25.62\% Loughborough 16.67\%)

- Borrow or return items (York 19.83\% Loughborough 30\%)

- Using Library resources to study (York 19.01\% Loughborough 18.33\%)

- Finding a group study space (York 11.57\% Loughborough 8.33\%)

For Sciences the two universities are similar in three areas:

- Finding individual study space (York 40.68\% Loughborough 16.6\%)

- Finding a group study space (York 11.86\% Loughborough 16.85)

- Borrow or return items (York 13.56\% Loughborough 14.98\%)

Unlike York, Loughborough Science Faculty students remaining highest scoring purposes focus around academic purpose rather than social (Using library resources to study $13.56 \%$ Using a PC $13.36 \%$ ). 
In the Social Sciences the universities are similar in four of the five top purposes of visit:

- Finding individual study space (York 29.61\% Loughborough 21.18\%)

- Using resources to study (York 17.86\% Loughborough 14.12\%)

- Finding a group study space (York 12.29\% Loughborough 10.2\%)

- Borrow or return items (York 9.5\% Loughborough 21.57\%)

Further results can be seen figures 3,4 and 5 .

Arts and Humanities

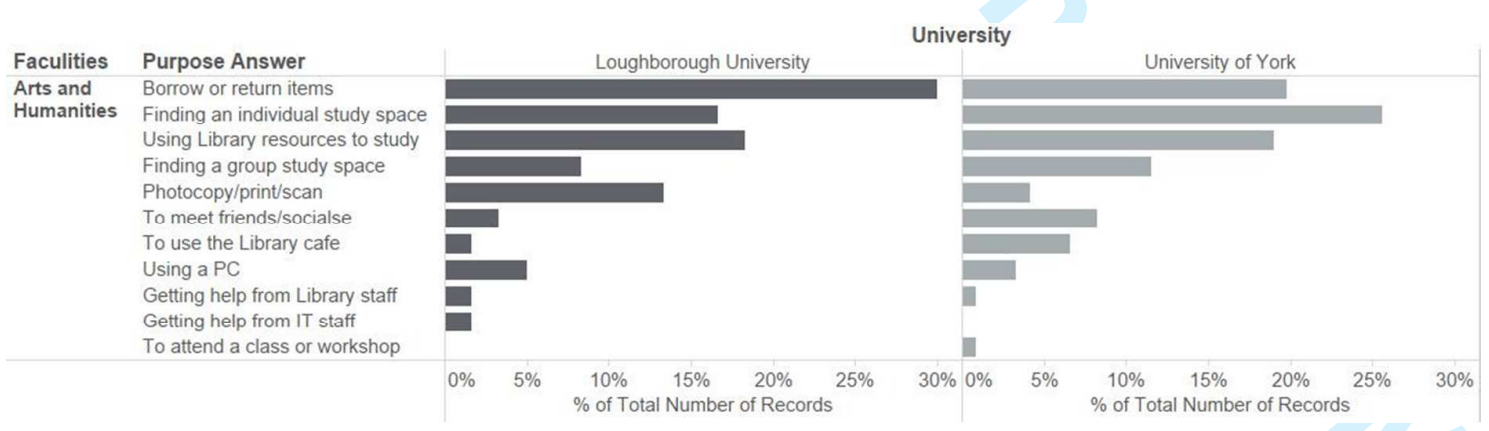

Figure. 3

Sciences 


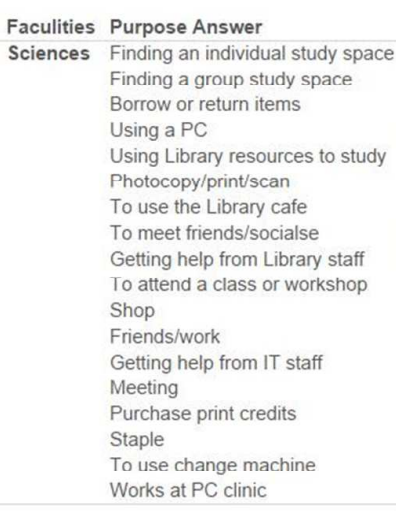

Loughborough University

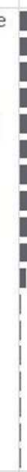

University

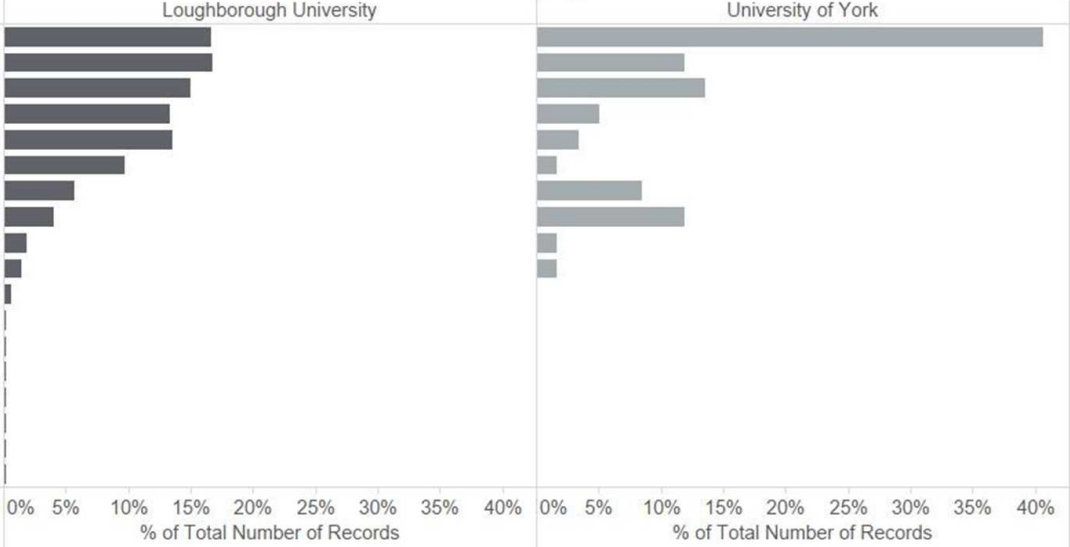

Figure 4.

Social Sciences
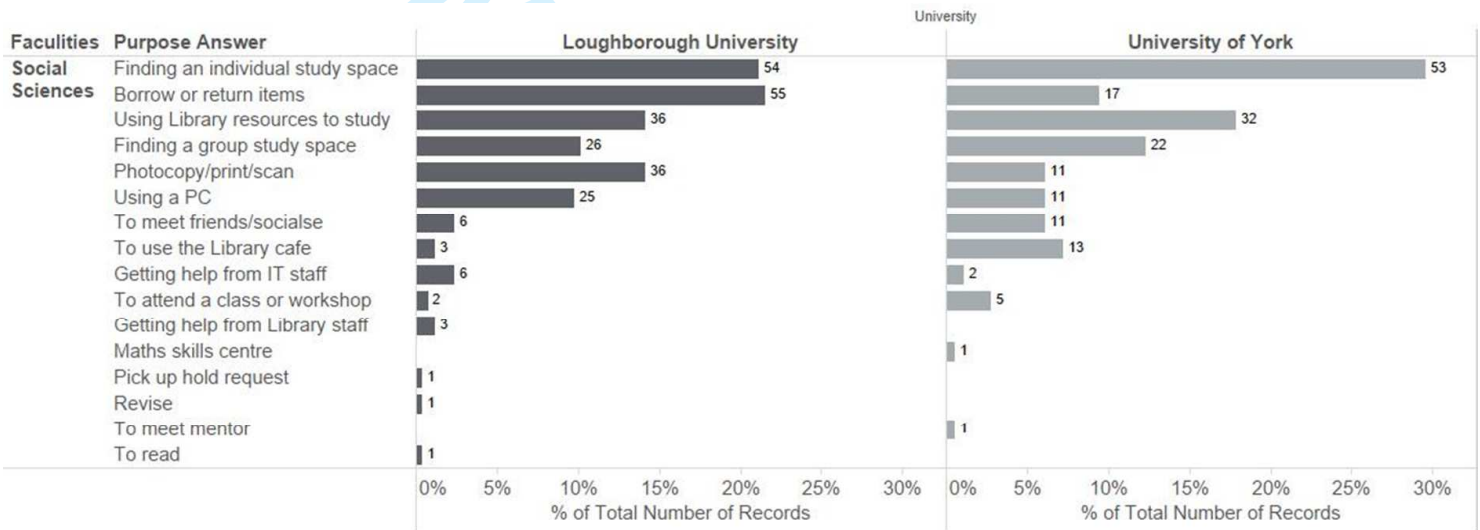

Figure 5.

\section{Use of spaces outside of the library}

\begin{tabular}{|l|l|l|l|l|l|l|}
\hline $\begin{array}{l}\text { Use of } \\
\text { other } \\
\text { Space }\end{array}$ & $\begin{array}{l}\text { \% UG } \\
\text { Loughborough }\end{array}$ & $\begin{array}{l}\text { \% UG } \\
\text { York }\end{array}$ & $\begin{array}{l}\text { \% PGT } \\
\text { Loughborough }\end{array}$ & $\begin{array}{l}\text { \% PGT } \\
\text { York }\end{array}$ & $\begin{array}{l}\text { \% PGR } \\
\text { Loughborough }\end{array}$ & $\begin{array}{l}\text { \% PGR } \\
\text { York }\end{array}$ \\
\hline Yes & 64.43 & 47.15 & 67.92 & 75.86 & 86.96 & 70 \\
\hline No & 35.57 & 52.85 & 32.08 & 24.14 & 13.04 & 30 \\
\hline
\end{tabular}


From the results it is clear that at both universities, all user groups do use other study spaces other than the Library. A higher percentage of undergraduates at Loughborough make use of other study spaces $(64.43 \%$ rather than $47.15 \%$ at York). Just over half of the York undergraduates do not use alternative study spaces at all.

Between two institutions results for taught postgraduates are very similar, with $67.92 \%$ of students using alternative space at Loughborough, and $75.86 \%$ at York. A slightly higher differential appears amongst postgraduate research students, with $86.96 \%$ of Loughborough students using other space and $70 \%$ at York.

These results reflect the differing estates strategies of the two institutions, in that Loughborough has developed a strategy looking at the provision of informal learning spaces across campus. Part of this approach has been to run a joint project at Loughborough between the Library, IT and Corporate Services in developing a campus map and highlighting other available study spaces.

At York, study space is concentrated in the University Library on the Heslington West campus, although new concentrations of study space are in plan for delivery over the next two years. These new areas may influence uptake of study space in the library, though for many undergraduates use of the Library (both at York and Loughborough) revolves around resource focussed activity ("Borrow or return" "Using library resources to study").

Devices brought to the library by user group

\begin{tabular}{|l|l|l|l|l|l|l|}
\hline Device & $\begin{array}{l}\text { \% UG } \\
\text { Loughborough }\end{array}$ & $\begin{array}{l}\text { \% UG } \\
\text { York }\end{array}$ & $\begin{array}{l}\text { \% PGT } \\
\text { Loughborough }\end{array}$ & $\begin{array}{l}\% \\
\text { PGT } \\
\text { York }\end{array}$ & $\begin{array}{l}\text { \% PGR } \\
\text { Loughborough }\end{array}$ & $\begin{array}{l}\text { \% PGR } \\
\text { York }\end{array}$ \\
\hline Laptop & 44.25 & 46.11 & 43.40 & $\begin{array}{l}48.2 \\
8\end{array}$ & 47.83 & 40 \\
\hline Tablet & 9.21 & 13.99 & 7.55 & $\begin{array}{l}17.2 \\
4\end{array}$ & 8.7 & 10 \\
\hline Both & 3.07 & 6.22 & 5.66 & $\begin{array}{l}10.3 \\
4\end{array}$ & - & - \\
\hline None & 43.48 & 33.68 & 43.40 & $\begin{array}{l}24.1 \\
4\end{array}$ & 43.48 & 50 \\
\hline
\end{tabular}

A high percentage of the undergraduate respondents at York had brought their own device; be it laptop or tablet, to the library whilst at Loughborough this was almost an even split. This is also the case with Taught Postgraduates as well; York users are more likely to bring their own devices than at Loughborough. At both institutions 
there is a more even split between those bringing some form of device and those not.

This would seem to indicate that whilst BYOD is strong in both institutions there is still likely to be some reliance on fixed IT workstations. It is worthwhile noting that at York the overall majority of user spaces have power to worktop, and good wifi connectivity. At Loughborough wifi is available throughout the library, with upgrades planned for this autumn with a significant proportion of all study spaces having access to power or a fixed PC.

\section{Frequency of use}

For undergraduates, usage tends to fall into the weekly or monthly parameters.

\begin{tabular}{|l|l|l|}
\hline Daily usage & & \\
\hline & Loughborough \% & York \% \\
\hline UG 1 & 16.98 & 31.11 \\
\hline UG 2 & 21.05 & 50.75 \\
\hline UG 3 & 31.18 & 60.00 \\
\hline UG 4 & 36.21 & 25.00 \\
\hline
\end{tabular}

\begin{tabular}{|l|l|l|}
\hline $\begin{array}{l}\text { Weekly } \\
\text { usage }\end{array}$ & Loughborough \% & \\
\hline & 73.58 & York \% \\
\hline UG 1 & 66.17 & 64.44 \\
\hline UG 2 & 60.22 & 47.76 \\
\hline UG 3 & 60.34 & 34.6 \\
\hline UG 4 & & 50.00 \\
\hline
\end{tabular}

Here we see a higher daily use in York, which may be influenced by the larger take up of space elsewhere by Loughborough students. Daily usage is also stronger after the first year of study. Weekly use is higher at Loughborough.

Taught postgraduate students show a similar pattern

\begin{tabular}{|l|l|l|}
\hline Usage & Loughborough \% & York \% \\
\hline
\end{tabular}




\begin{tabular}{|l|l|l|}
\hline Daily & 35.85 & 58.62 \\
\hline Weekly & 54.72 & 41.38 \\
\hline
\end{tabular}

Whilst amongst research postgraduate students monthly usage begins to evidence itself more strongly, though the number of respondents at York in this category was very low.

\begin{tabular}{|l|l|l|}
\hline Usage & Loughborough \% & York \% \\
\hline Daily & 39.13 & 30.00 \\
\hline Weekly & 21.74 & 60.00 \\
\hline Monthly & 20.09 & 10.00 \\
\hline
\end{tabular}

\section{Conclusions}

\section{Student use of space}

Where high quality, dedicated study space exists across universities students will use these facilities in addition to space provided by the library. Students look to the library to provide them with space both for individual and group study, but also take up the opportunity to use the wide range of facilities and services provided in the Library space. Additional facilities, alongside the traditional use of resources, are now one of the primary factors influencing the utilisation of the Library. These results would indicate that that there is a need to provide a range of study spaces within the Library to cater for different needs and that resources (including print materials) are an essential component of the study experience for students.

\section{Working together}

Working collaboratively with another institution has proved to be a very beneficial experience and the rise in collaborative tools has enabled this partnership considerably. Loughborough's natural competitiveness however did mean there was a concerted effort to gain more survey results than gathered by those at York. As a consequence the method of data analysis needed to take this into account and ensure that all results were compared equally and fairly.

\section{Next steps}

Both institutions have already undertaken further investigation into use of study space, Loughborough has carried out interviews with a number of grab and go participants. These interviews; have provided additional data to aid service 
improvement within the Library, will help inform work across the institution with regard to informal learning space provision and may support some financial cases.

York has made further investigation into the motivation for using study space, both in the Library and elsewhere. This will be followed by interviews with library users during the Autumn term 2015, after which all these results will be compiled, studied and published.

Both libraries will be repeating the original survey in the Spring term 2016 to begin to build up longitudinal data on library use.

\section{References}

Survey carried out by One Poll. 2,000 UK students were surveyed online in June 2015. Commissioned by Association of University Directors of Estates (AUDE) Accessed from the AUDE website - October 28th 2015 http://www.aude.ac.uk/news-and-events/news/facilities-a-key-factor-in-choosinguniversity/

\section{Appendix 1 User questions asked at both University Libraries}

Q.1 Which university do you belong to

- Loughborough

- York

Q.2 Which course do you belong to? (includes the response "other" - please specify)

Q.3What is your status?

- UG 1

- UG2

- Finalist

- Taught PG

- Research PG

- Academic staff

- Support/Admin staff

- Other - please specify

Q.4 What is the purpose of your visit today? (people can select multiple answers)

- Finding an individual study space

- Finding a group study space

- Using resources to study

- Meet friends/eat/socialise

- Getting help from staff - Library

- Getting help from staff - IT

- Borrow or return items

- Use a PC 
- Photocopy/print/scan

- To attend class or workshop

- Use the Library cafe

- Other - add a text box to capture the 'other'
Daily
Weekly
Monthly
Quarterly
Other

Q.5 How often do you visit the Library

\begin{abstract}
Q.6 Do you use other spaces on campus to study/work?
Q.7 Have you brought a laptop or tablet to use today?

Q.8 Can we talk to you again to talk about study space?
\end{abstract}

\begin{abstract}
Appendix 2 - Information about Loughborough University and University of York
\end{abstract}
Loughborough University was founded in 1966 and has over 15,000 students. It is regularly placed in the top 15 UK university league tables. It offers the full range of academic disciplines (apart from law and medicine). It has two campuses, the Loughborough Campus covers 438 acres and is located in the centre of England. In 2015 , it opened a smaller postgraduate campus in London. The Library stores 750,000 items and employs 85 staff. There are 1370 study spaces in the Library and access is provided to over 400 fixed PCs.

Founded on principles of excellence, equality and opportunity for all, the University of York opened in 1963 with just 230 students, it is now home to more than 16,500 students from 120 countries. It is a member of the Russell Group and one of just six post-war universities to have appeared in the world top 100. The University Library has two sites, one at Kings Manor in the city centre, and is responsible for York Minster Library. The Borthwick Institute for Archives are based within the Library at the Heslington campus. The Library's collections include over 1.2 million items, access to over 60,000 print and electronic journals, thousands of e-books, audiovisual material, images, music scores, statistics, data sets and other electronic resources. There are 1321 study spaces in the main University Library. 